\title{
PEMILIHAN PROGRAM PENGENTASAN KEMISKINAN MELALUI PENGEMBANGAN MODEL PEMBERDAYAAN MASYARAKAT DENGAN PENDEKATAN SISTEM
}

\author{
Sutikno ${ }^{1}$, Eddy Setiadi Soedjono ${ }^{2}$, Agnes Tuti Rumiati ${ }^{1}$, dan Lantip Trisunarno ${ }^{3}$ \\ ${ }^{1}$ Jurusan Statistika Fakultas MIPA Institut Teknologi Sepuluh Nopember Surabaya \\ ${ }_{2}^{2}$ Jurusan Teknik Lingkungan Fakultas TSP Institut Teknologi Sepuluh Nopember Surabaya \\ ${ }^{3}$ Jurusan Teknik Industri Fakultas TI Institut Teknologi Sepuluh Nopember Surabaya \\ Jalan Kampus ITS Sukolilo Tromol Pos 900 Surabaya Jawa Timur 60008 Telepon (031) 5937774, 5994251
}

Diterima 26 Desember 2009/ Disetujui 5 Mei 2010

\begin{abstract}
This research aims to compile the programs for poverty alleviation by community empowerment model and review the determination program as effectiveness evaluation poverty alleviation program which still can't be worked properly. Stages the compiling program of poverty alleviation is mapping the socioeconomic conditions of the poor, basic infrastructure conditions, socio-cultural issues, and potential issues; identifying the hopes and predicting the economic development opportunities; creating the poverty alleviation program by SWOT analysis and planning implementation program with KPD. Based on the result of SWOT and scoring analysis, the selected programs are training and assistance, the establishment of cooperative saving and loans, clean water for poor households, rural development with the utilization of clean water, household waste management, and package education program $A, B$, and $C$.
\end{abstract}

Keywords: poverty alleviation, SWOT analysis, community empowerment, entrepreneurship

\begin{abstract}
Abstrak: Penelitian ini bertujuan menyusun program-program pengentasan kemiskinan melalui model pemberdayaan masyarakat dan mengkaji kembali proses penentuan program sebagai evaluasi efektivitas program pengentasan kemiskinan yang dinilai masih belum dapat berjalan dengan baik. Tahapan dalam penyusunan program pemberdayaan masyarakat untuk pengentasan kemiskinan adalah memetakan kondisi sosial ekonomi masyarakat miskin, kondisi infrastruktur dasar, persoalan sosial-budaya, dan potensi yang dimiliki; mengidentifikasi keinginan, harapan, dan memprediksi peluang pengembangan ekonomi; membuat perencanaan program pengentasan kemiskinan melalui analisis SWOT dan perencanaan program pendampingannya; pembentukan KPD, konfirmasi dan rencana implementasi program bersama KPD. Berdasarkan hasil analisis SWOT dan scoring, program terpilih di antaranya pelatihan dan pendampingan wirausaha, pendirian koperasi simpan pinjam, pengadaan air bersih untuk RTM, pengembangan desa dengan pendayagunaan air bersih, penanganan sampah rumahtangga, dan program pendidikan paket $A, B$, dan $C$.
\end{abstract}

Kata kunci: pengentasan kemiskinan, analisis SWOT, pemberdayaan masyarakat, wirausaha

\section{PENDAHULUAN}

Menurut BPS provinsi Jawa Timur (2009), jumlah penduduk miskin (yang berada di bawah garis kemiskinan) di Jawa Timur sampai dengan bulan Maret 2009 mencapai 6,02 juta jiwa (16,68 persen). Persentase penduduk miskin yang tinggal di pedesaan adalah lebih besar 64,32 persen, sedangkan sisanya 35,68 persen tinggal di perkotaan. Persentase penduduk miskin ini relatif berkurang dibanding dengan tahun 2008 yang mencapai 6,651 juta 
jiwa (18,51 persen) dengan persentase penduduk miskin tinggal di pedesaan juga lebih besar 65,26 persen. Selama periode 2001-2006 jumlah penduduk miskin berfluktuasi dari tahun ke tahun. Pada periode 2001-2004 jumlah penduduk miskin cenderung menurun, namun pada tahun 2005-2006 justru terjadi sebaliknya yaitu jumlah penduduk miskin yang meningkat cukup drastis menjadi sebesar 7,14 juta jiwa (19,95 persen) pada tahun 2005 dan 7,68 juta jiwa (21,09 persen) pada tahun 2006. Tahun 2007-2009 jumlah dan persentase penduduk miskin mengalami penurunan kembali setiap tahunnya, yaitu hanya berkisar 1-2 persen.

Secara umum program-program pengentasan kemiskinan dapat dikategorikan menjadi dua kelompok besar (Bappenas, 2007). Kelompok pertama terdiri dari program-program yang ditujukan hanya pada orang miskin. Jika program-program ini dilaksanakan secara efektif, maka keluarga-keluarga miskin yang benarbenar akan menikmati hampir seluruh manfaatnya. Kelompok program ini sangat tergantung pada pentargetan awal yang akurat untuk memastikan bahwa penerima manfaat teridentifikasi dengan benar. Contoh programnya adalah bantuan beras untuk rakyat miskin (RASKIN) (2007), BLT (2006), Jaminan Kesehatan (Askeskin) (2006), PNPM Mandiri (2007), PKPS BBM (2005). Kelompok kedua terdiri dari programprogram yang ditujukan tidak hanya untuk rakyat miskin tapi juga untuk masyarakat dari semua golongan pendapatan, tapi secara proporsional akan memberi manfaat lebih bagi rakyat miskin. Contoh program ini adalah pendanaan pelayanan kesehatan, penyediaan obat generik, dan pengurangan biaya sekolah, BOS (2005).

Program-program penanggulangan kemiskinan di Jawa Timur yang telah dilaksanakan oleh pemerintah pusat maupun daerah di antaranya: Gerdutaskin (1997), PKPS BBM (2003; 2005), PNPM Mandiri (2008). Empat program pertama sebagian besar bersifat top-down, sedangkan program PNPM mandiri proses penentuannya bersifat bottom-up yang lebih menekankan pada peran aktif masyarakat mulai dari proses pemilihan program hingga monitoring dan evaluasi (monev). Programprogram yang bersifat bottom-up juga masih belum optimal meskipun tingkat kegagalannya lebih rendah jika dibanding dengan program top-down. Selain itu, program-program lainnya yang juga berperan penting dalam pengentasan kemiskinan antara lain: Raskin (2002), Jamkesmas (2005), BLT (2006), BOS (2007), PKH (2007), KUR (2007).

Sampai saat ini efektifitas program-program pengentasan kemiskinan yang telah diuji cobakan pemerintah baik yang bersifat top-down maupun bottom-up dinilai masih belum dapat berjalan dengan baik. Hal ini ditandai dengan rendahnya tingkat keberhasilan program-program yang bersifat top-down karena masyarakat sasaran program tidak dilibatkan dalam penentuan program dan aktivitas monev sehingga masyarakat seperti mendapatkan hibah dari pemerintah dan tidak perlu mengembalikan lagi. Program-program yang bersifat bottom up juga demikian meski tingkat kegagalannya lebih rendah dibanding dengan program topdown.

Dengan demikian, dapat dikatakan bahwa program-program pengentasan kemiskinan yang telah dilaksanakan belum secara signifikan mampu menurunkan jumlah penduduk miskin sehingga memunculkan pertanyaan tentang sebab banyaknya program penanggulangan kemiskinan yang tidak efektif. Oleh karena itu, diperlukan pengkajian kembali proses penentuan program-program kemiskinan sebagai evaluasi efektivitas program pengentasan kemiskinan yang dinilai masih belum dapat berjalan dengan baik.

Pemberdayaan masyarakat merupakan upaya untuk meningkatkan harkat dan martabat lapisan masyarakat yang dalam kondisi sekarang tidak mampu untuk melepaskan diri dari perangkap kemiskinan dan keterbelakangan. Dengan kata lain, pemberdayaan adalah memampukan dan memandirikan masyarakat. Pemberdayaan masyarakat juga dapat diwujudkan dengan menerapkan prinsip-prinsip dasar pendampingan masyarakat, yaitu (Karsidi, 2002): (1) Belajar dari masyarakat; (2) Pendamping sebagai fasilitator, masyarakat sebagai pelaku; (3) Saling belajar, saling berbagi pengalaman.

Pada penelitian ini diterapkan pengembangan model pemberdayaan masyarakat 
untuk memilih program pengentasan kemiskinan di Desa Sumberdodol, Kecamatan Benjeng, Kabupaten Magetan dan Desa Metatu, Kecamatan Panekan, Kabupaten Gresik.

Kemiskinan dan Program Kemiskinan. Potret tentang kemiskinan cenderung memperlihatkan suatu kondisi yang kompleks, berdiri sendiri, ataupun yang berinteraksi antara faktor sosial, budaya, ekonomi, dan politik (Rachmat, 1997). Dengan keluarnya Inpres No.5 Tahun 1993 diharapkan sebagai suatu kekuatan dan momentum pembangunan bagi masyarakat dalam membantu percepatan pengurangan proses kemiskinan, khususnya di desa-desa tertinggal (Bappenas, 1994).

Menurut BPS, kemiskinan adalah ketidakmampuan untuk memenuhi standar dari kebutuhan dasar, baik makanan maupun bukan makanan. Standar ini disebut sebagai garis kemiskinan, yakni kebutuhan dasar makanan setara 2100 kalori energi per kapita per hari, ditambah nilai pengeluaran untuk kebutuhan dasar bukan makanan yang paling pokok (BPS, 2006).

Persoalan kemiskinan merupakan persoalan yang sangat kompleks. Banyak faktor yang berperan menjadi penyebab kemiskinan. Menurut Yasa (2007) ketidak-beruntungan yang melekat pada keluarga miskin, keterbatasan kepemilikan aset (poor), kelemahan kondisi fisik (physically weak), keterisolasian (isolation), kerentaan (vulnerable), dan ketidakberdayaan (powerless) adalah berbagai penyebab mengapa keluarga miskin selalu kekurangan dalam memenuhi dasar hidup, seperti pangan, sandang, papan, kesehatan, dan pendidikan layak untuk anak-anaknya. Kondisi serba kekurangan dari masyarakat miskin tersebut menyebabkan mereka tidak dapat menjalankan fungsi sosialnya. Selain itu, kultur kemiskinan yang masih kental dalam masyarakat dengan budaya tolong-menolong pada satu sisi dapat bersifat positif, namun di sisi yang lain juga dapat mengaburkan arti kemiskinan yang sebenarnya. Orang yang sebenarnya sangat miskin, merasa tidak terlalu miskin karena bantuan sosial di sekelilingnya. Kondisi kemiskinan diperparah oleh kewajiban sosial yang ditanggung keluarga miskin, seperti kewajiban menyumbang. Situasi yang seperti ini menyebab- kan berbagai program penanggulangan kemiskinan dan pembangunan pedesaan menghadapi hambatan dalam pelaksanaannya (Listyaningsih, 2004).

Beberapa langkah konkrit yang dilakukan pemerintah sebagai upaya percepatan penanggulangan kemiskinan, dijabarkan dalam berbagai program yang diharapkan menjadi instrumen utama dalam kegiatan tersebut. Berbagai program yang telah dilaksanakan termasuk cakupan dalam program kelompok pertama maupun kedua (Bappenas, 2007) di antaranya tampak dalam Tabel 1.

Pemberdayaan Masyarakat. Pemberdayaan adalah bagian dari paradigma pembangunan yang memfokuskan perhatiannya kepada semua aspek yang prinsipil dari manusia di lingkungannya yakni mulai dari aspek intelektual (Sumber Daya Manusia), aspek material dan fisik, sampai kepada aspek manajerial (Rahayu, 2008). Aspek-aspek tersebut bisa jadi dikembangkan menjadi aspek sosial-budaya, ekonomi, politik, keamanan, dan lingkungan

Strategi pembangunan yang bertumpu pada pemberdayaan dipahami sebagai suatu proses transformasi dalam hubungan sosial, ekonomi, budaya, dan politik masyarakat. Implementasinya merupakan suatu konsukensi dari pergeseran paradigma pembangunan nasional yang mengarah pada tercapainya upaya pembangunan yang berpusat pada manusia (people centered development). Pendekatan utama dalam konsep pemberdayaan adalah masyarakat tidak dijadikan obyek, tetapi subyek dari pembangunan. Pendekatan tersebut harus terarah (targetted), mengikutsertakan atau bahkan dilaksanakan masyarakat sebagai sasaran, dan menggunakan pendekatan kelompok.

Analisis SWOT. Analisis SWOT adalah identifikasi berbagai faktor secara sistematis untuk merumuskan strategi perusahaan. Analisis ini didasarkan pada logika yang dapat memaksimalkan kekuatan (Strength) dan peluang (Opportunities), namun secara bersamaan dapat meminimalkan kelemahan (Weaknesses) dan ancaman (Threats). Proses pengambilan keputusan strategis selalu berkaitan dengan pengembangan misi, tujuan strategi, dan kebijakan organisasi. Dengan demikian perencana strategis harus menganalisis faktor-faktor stra- 
Tabel 1. Program-Program Pengentasan Kemiskinan

\begin{tabular}{|c|c|c|c|c|}
\hline No & Jenis Bantuan & Waktu & Sumber bantuan & Bentuk/Jumlah \\
\hline 1. & PNPM Mandiri & 2007 & Pusat (Menkokesra) & $\begin{array}{l}\text { Dana 1,448 trilliun dan } \\
\text { benih tanaman pertanian }\end{array}$ \\
\hline 2. & PKPS BBM & 2005 & Pusat & $\begin{array}{l}\text { Pendidikan, kesehatan, } \\
\text { infrastruktur pedesaan }\end{array}$ \\
\hline 3. & Raskin & 2002 & Pusat & Uang dan Beras \\
\hline 4. & $\begin{array}{l}\text { Program Asuransi Kesehatan } \\
\text { untuk orang miskin } \\
\text { (Askeskin) }\end{array}$ & 2005 & $\begin{array}{l}\text { Pusat (Departemen } \\
\text { Kesehatan) }\end{array}$ & Layanan Kesehatan \\
\hline 5. & $\begin{array}{l}\text { Bantuan Operasional Sekolah } \\
\text { (BOS) }\end{array}$ & $2007-2008$ & Pusat (Mendiknas) & $\begin{array}{l}\text { Dana untuk PSB } \\
\text { (50,2 dan } 61,4 \text { trillun) }\end{array}$ \\
\hline 6. & $\begin{array}{l}\text { Program Keluarga Harapan } \\
\text { (PKH) }\end{array}$ & 2007 & Pusat & $\begin{array}{l}\text { Uang untuk pendidikan } \\
\text { dan kesehatan }\end{array}$ \\
\hline 7. & Gerdu Taskin & 2005 & Provinsi & Modal usaha \\
\hline 8. & $\begin{array}{l}\text { Usaha mikro kecil dan } \\
\text { menengah (UMKM). }\end{array}$ & 1993 & Pusat & 2\% laba BUMN, Usaha \\
\hline 9. & IDT (Inpres Desa Tertinggal) & 1988-1998 & Pusat & Pembangunan Desa \\
\hline
\end{tabular}

tegis perusahaan dalam kondisi yang ada saat ini. Hal ini sering disebut dengan analisis situasi atau kondisi. Model yang popular untuk analisis situasi adalah analisis SWOT (Rangkuti, 1997).

Hasil Penelitian Sebelumnya. Programprogram kemiskinan di Jawa Timur telah banyak dilakukan oleh pemerintah, baik pusat maupun daerah. Proses penentuan program tersebut sebagian besar murni bersifat top-down, sehingga seringkali penerima sasaran program merasa tidak memiliki tanggungjawab terhadap keberlanjutan program. Program-program pengentasan kemiskinan yang telah dilaksanakan sebagian besar keterukuran keberhasilan program belum ada. Setelah program-program tersebut selesai dilaksanakan, keberlanjutannya tidak jelas.

Dengan demikian seringkali muncul program baru, namun sebenarnya sejenis. Di samping itu program-program pengentasan kemiskinan bersifat seragam tanpa memperhatikan karakteristik masyarakat penerima program (sasaran). Padahal setiap wilayah mempunyai karakteristik baik masyarakat, budaya, dan wilayah yang berbeda-beda.

Beberapa penelitian UP3D yang terkait dengan monitoring dan evaluasi program pe- ngentasan kemiskinan di antaranya monitoring dan evaluasi Program Kompensasi Pengurangan Subsidi Bahan Bakar minyak (PKPS BBM) tahun 2003 dan 2005. Program PKPS BBM berasal dari pemerintah pusat. Beberapa kesimpulan dari monitoring dan evaluasi program tersebut adalah ragam program cukup banyak sehingga efektivitas program masih belum optimal. Karena program bersifat top-down, sehingga sebagian besar sasaran program (keluarga miskin) menganggap program tersebut hibah dan tidak perlu dipertanggungjawabkan.

Tahun 2006, UP3D melakukan monitoring evaluasi program PAM DKB, yaitu program penanggulangan dampak kenaikan BBM yang dilakukan oleh Pemerintah Provinsi Jawa Timur. Hasil penelitian tersebut menyimpulkan bahwa terdapat tumpang tindih program kemiskinan dengan pemerintah pusat. Tingkat efektivitas program yang rendah karena penerima program merasa tidak diikutkan dalam proses penentuan program. UP3D $(2008 ; 2009)$ telah melakukan penelitian tentang CSR (Corporate Social Respinsibility) di wilayah Tuban bekerjasama dengan PT. Holcim Indonesia. Proses penyusunan program diawali dari pemetaan sosial dan penggalian informasi sumber 
penghidupan serta aktivitas bisnis yang dilakukan oleh calon sasaran program. Di samping itu digali permasalahan, persepsi, dan harapan masyarakat. Beberapa permasalahan yang digali berkaitan dengan infrastruktur dasar (air bersih dan sanitasi), pendidikan, kesehatan, dan aktivitas bisnis. Selanjutnya disusun daftar masalah dan kebutuhan serta program-program yang sesuai dengan wilayah. Proses penyusunan program masyarakat dilibatkan (bottom-up), namun juga dilakukan top-down ketika penentuan prioritas program.

\section{METODE PENELITIAN}

\section{Proses Umum}

Secara umum proses pengembangan model pemberdayaan untuk pengentasan kemiskinan terdiri atas 5 tahapan yaitu (1) studi literatur, penyusunan instrumen pengumpulan data (kuisioner, panduan wawancara mendalam), penyusunan disain sampling; (2) pengumpulan data primer, (survey) dan data sekunder; (3) analisis data untuk menggambarkan kondisi yang ada serta analisis dalam pemilahan kebutuhan, penyusunan program, (4) diskusi kelompok terfokus (FGD) dan pembentukan Kelompok Perwakilan Desa (KPD), (5) konfirmasi dan rencana implementasi program kemiskinan bersama KPD. Proses umum penelitian disajikan pada Gambar 1.

\section{Lokasi dan Pengumpulan Data}

Lokasi adalah di Desa Sumberdodol, Kecamatan Benjeng, Kabupaten Magetan dan Desa Metatu, Kecamatan Panekan, Kabupaten Gresik.

Data yang dikumpulkan terdiri atas data primer, data sekunder, serta Focus Group Discussion (FGD). Data sekunder mencakup data geografi dan monografi desa, serta monografi

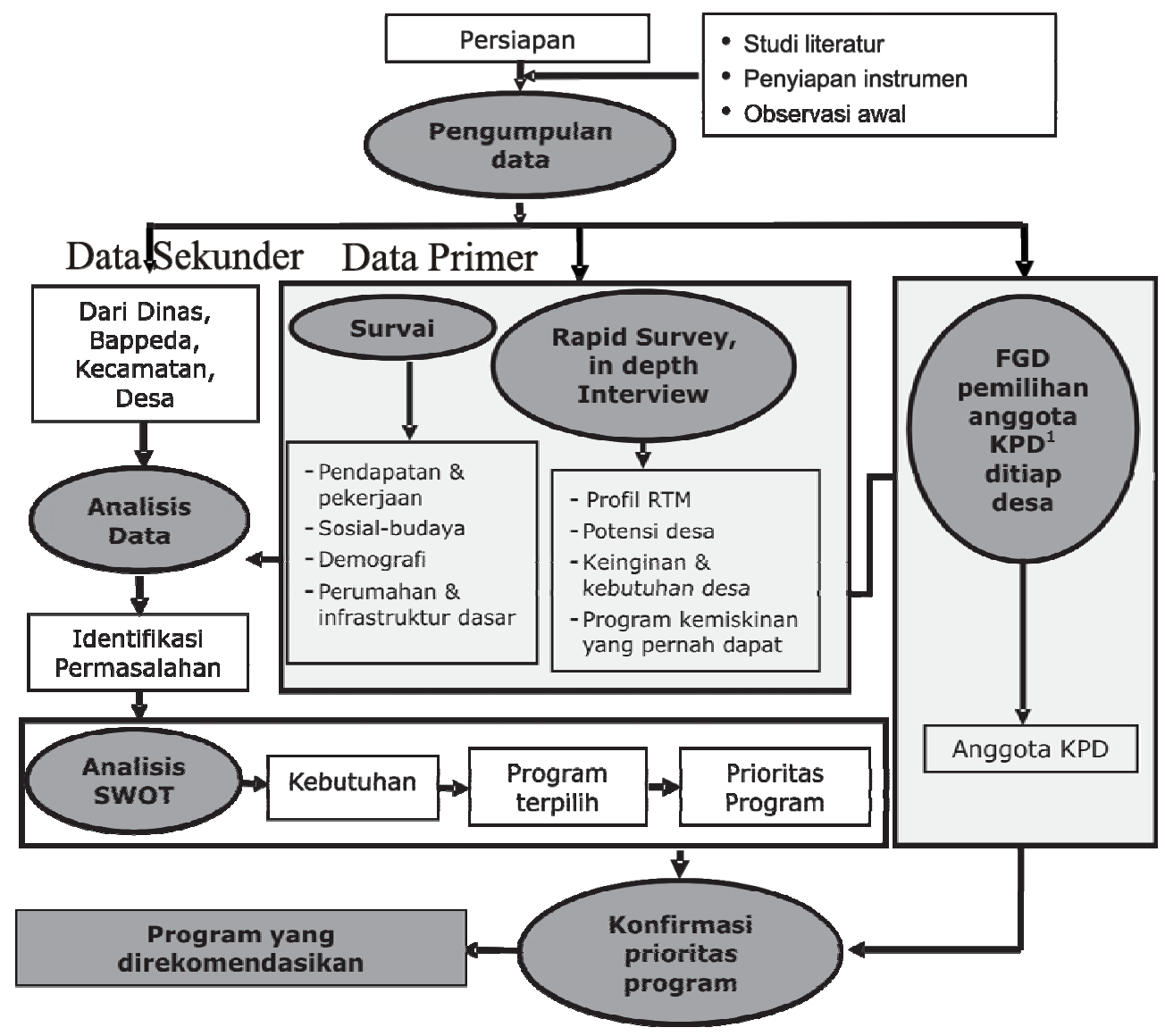

Gambar 1. Diagram Alir Proses Penelitian 
rumahtangga miskin. Pengumpulan data primer dilakukan melalui tiga proses yaitu survai, rapid survai dan in depth interview.

Variabel-variabel yang digunakan adalah variabel-variabel dari data sekunder dan primer yang dikelompokkan menjadi tiga aspek, yaitu: (1) Aspek Sosial Budaya, (2) Aspek Ekonomi, dan (3) Aspek Lingkungan.

\section{HASIL DAN PEMBAHASAN}

Metode analisis meliputi (1) analisis deskriptif, (2) analisis SWOT yang digunakan untuk menganalisis situasi saat ini berkaitan dengan aspek ekonomi, sosial-budaya dan lingkungan Desa Sumberdodol dan Metatu, dan (3) Pembobotan scoring

Digunakan untuk proses pemilihan program prioritas. Kriteria yang digunakan untuk memilih program prioritas pemberdayaan masyarakat adalah sebagai berikut; (1) Manfaat program, (2) Tingkat kepentingan, (3) Kemungkinan keberhasilan, dan (4) Impact.

Metode analisis data disajikan pada Gambar 2.

Pada tahap analisis dan pembahasan proses pemilihan program pengentasan kemiskinan ini akan dilakukan studi kasus di Desa Metatu, Kecamatan Benjeng, Kabupaten Gresik dan Desa Sumberdodol, Kecamatan Panekan, Kabupaten Magetan.

\section{Program-Program Bantuan Pengentasan Kemiskinan dan Dampaknya terhadap RTM}

Berdasarkan identifikasi program-program bantuan kemiskinan, sebagian besar rumahtangga miskin yang mendapatkan bantuan BLT dan raskin. Tabel 1 menyajikan jenis program bantuan kemiskinan yang pernah ada di Desa Metatu dan Sumberdodol. Jenis bantuan kemiskinan yang diterima RTM cukup beragam baik bantuan langsung tunai, peminjaman modal, maupun infrastruktur dasar. Bantuan-bantuan tersebut masih minim pengem-bangan sumber daya manusia, seperti pelatihan-pelatihan keterampilan.

Program pengentasan kemiskinan yang sudah dijalankan cukup efektif. Namun, pada pengelolaan beberapa program bantuan melalui proses pendampingan, kesinambungan program kurang diperhatikan. Mereka hanya melaksanakan tugasnya pada saat pendampingan, ketika selesai melaksanakan tugasnya dan meninggalkan lokasi program yang sebelumnya berjalan menjadi terganggu, bahkan terancam bubar dan tidak terjadi kesinambungan program. Selain itu masih diperlukan penjelasan mengenai program yang berjalan pada masyarakat supaya diperoleh pemahaman yang benar terhadap program yang ada. Hal tersebut merupakan salah satu tugas pendamping ketika melakukan pendampingan terhadap program yang berjalan, sehingga terjadi transfer informasi dengan warga setempat dan diharapkan terjalin kesinambungan pada waktu-waktu berikutnya.

Secara umum warga sangat mendukung dan menerima dengan baik program pengentasan kemiskinan yang dijalankan. Namun keterlibatan masyarakat dalam program-program kemiskinan yang ada masih cukup minim, dikarenakan kemampuan Sumber Daya Manusia (SDM) yang terbatas. Sebagian besar memilih hanya menerima dan memanfaatkan. Program bantuan kemiskinan yang telah diberikan dianggap sangat membantu $(38,24$ persen) dan cukup membantu (33,33 persen) sebagian besar rumah tangga miskin (lihat Gambar 2).

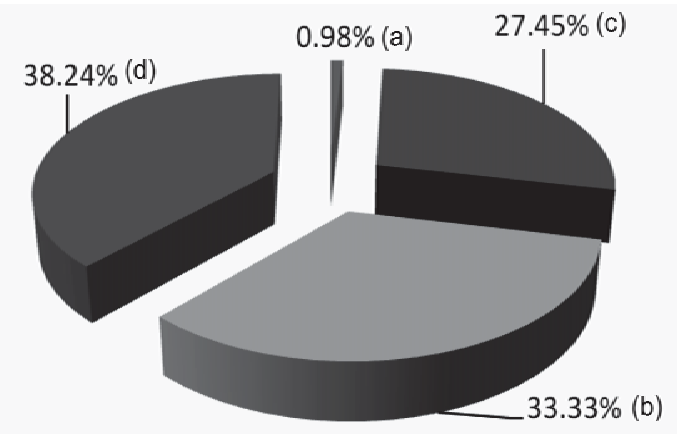
(a) Tidak membantu
(c) Kurang membantu
(b) $\backsim$ Cukup membantu
(d) Sangat membantu

Sumber: Survai 2009

\section{Gambar 2. Pendapat Masyarakat terhadap Program Bantuan}


Manfaat yang telah dirasakan di antaranya meringankan pemenuhan kebutuhan seharihari, menambah modal, beberapa fasilitas umum menjadi lebih baik dan meningkatkan kerukunan sosial antarwarga walaupun ada beberapa masyarakat belum merasa terbantu secara keseluruhan.

\section{Strategi Pengembangan RTM dan Pemilihan Program Analisis SWOT}

Analisis kebutuhan sebagai dasar pemilihan program dilakukan didasarkan pada analisis potensi dan permasalahan, keinginan masyarakat, dan analisis SWOT yaitu dengan memperhatikan kekuatan, kelemahan, peluang dan tantangan yang harus dihadapi. Aspek-aspek yang diperhatian meliputi aspek sosial budaya, lingkungan, maupun aspek ekonomi.

Adapun program-program yang dianalisis dengan metode SWOT berdasarkan aspek sosial budaya, ekonomi, dan lingkungan disajikan di Tabel 2, Tabel 3, dan Tabel 4.

\section{Program Potensial dan Prioritas Program untuk Pengentasan Kemiskinan}

Berdasarkan hasil analisis SWOT, dapat diten- tukan kebutuhan RTM dan program-program yang sesuai. Tabel 5, Tabel 6, dan Tabel 7 menjelaskan kebutuhan dan program potensial serta sasaran dan lokasi program.

\section{Pemilihan Prioritas Program}

Berdasarkan hasil perhitungan score didapatkan pilihan program sesuai peringkat skor. Tiga program yang terpilih berdasarkan nilai total skor tertinggi:

(1) Aspek sosial budaya: menciptakan usaha produktif, pelatihan dan pendampingan wirausaha, dan program penidikan paket $\mathrm{A}, \mathrm{B}$, dan C.

(2) Aspek ekonomi: Pelatihan dan pendampingan untuk keterampilan dan wirausaha, peningkatan keterampilan mencari peluang usaha, dan pendirian koperasi simpan pinjam.

(3) Aspek lingkungan: pengadaan air bersih, pengembangan desa dengan pendayagunaan air bersih, dan penanganan sampah rumahtangga.

Perhitungan skor disajikan di Tabel 8 , Tabel 9, dan Tabel 10.

Tabel 2. Program Kemiskinan

\begin{tabular}{|c|c|c|c|c|}
\hline No & Jenis Bantuan & Waktu & Sumber bantuan & Bentuk/Jumlah \\
\hline \multicolumn{5}{|c|}{---- (Desa Sumberdodol) ----- } \\
\hline 1 & PAM DKB & 2005 & Provinsi & Padat kerja (kambing 80 bergulir) \\
\hline 2 & PNPM (PPK) & $2005-2006$ & Pusat & Renovasi sekolah, perbaikan jalan \\
\hline 3 & PNPM Mandiri & 2007-skrg & Pusat & USP Perempuan \\
\hline 4 & Gerdu taskin & $2006-2007$ & Kabupaten & USP, penggemukan sapi \\
\hline 5 & PKPS BBM & $2007-2008$ & Pusat & BLT, JAMKESMAS \\
\hline 6 & $\begin{array}{l}\text { Desa model binaan } \\
\text { Gerdu Taskin }\end{array}$ & 2009 & $\begin{array}{l}\text { Bapemas Pemrov } \\
\text { Jatim, Dinas Pemb. } \\
\text { Masy Kab Magetan }\end{array}$ & $\begin{array}{l}\text { USP, Pengembangan kolam } \\
\text { renang desa }\end{array}$ \\
\hline 7 & Raskin & $2000-2009$ & $\begin{array}{l}\text { Pusat } \\
\text { (Desa Metatu) --- }\end{array}$ & Beras potong harga jadi $1600 / \mathrm{kg}$ \\
\hline 1. & PNPM Mandiri & 2003-2009 & Pemerintah Pusat & Simpan Pinjam \\
\hline 2. & PKPS BBM & 2003-2009 & Pusat & BLT, JAMKESMAS \\
\hline 3. & Raskin & & Pusat & Sembako \\
\hline 4. & $\begin{array}{l}\text { Desa model binaan } \\
\text { Gerdu Taskin }\end{array}$ & 2009-sekarang & $\begin{array}{l}\text { Pemrov Jatim, } \\
\text { Dinas Pemberdayaan } \\
\text { Masy. Kabupaten } \\
\text { Gresik }\end{array}$ & USP \\
\hline
\end{tabular}

Sumber: Hasil Wawancara Mendalam, 2009 
Tabel 4. SWOT Aspek Lingkungan

\begin{tabular}{|c|c|c|c|c|}
\hline SubAspek & Faktor Pendukung & Kekurangan & Peluang & Tantangan \\
\hline Air Bersih & $\begin{array}{ll} & \text { Kemampuan } \\
\text { kuat untuk } \\
\text { memanfaatkan } \\
\text { sumber air } \\
\text { bersih di } \\
\text { Sumberdodol } \\
\text { Adanya telaga } \\
\text { untuk penam- } \\
\text { pungan air }\end{array}$ & ○ Lokasi jauh & $\begin{array}{ll}\text { Adanya bumi } \\
\text { perkemahan }\end{array}$ & \\
\hline $\begin{array}{l}\text { Air Limbah } \\
\text { Rumahtangga }\end{array}$ & 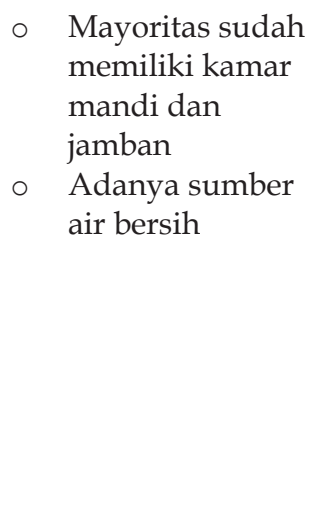 & 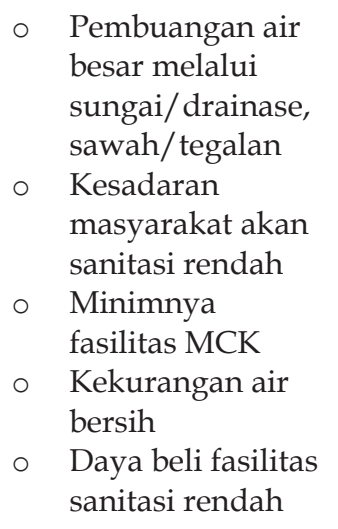 & $\begin{array}{l}\text { Adanya program } \\
\text { pemerintah kabu- } \\
\text { paten terkait } \\
\text { kesehatan masya- } \\
\text { rakat }\end{array}$ & \\
\hline Sampah & $\begin{array}{ll}\circ & \text { Terdapat Tem- } \\
\text { pat Pembuangan } & \text { Sampah (TPA) } \\
& \text { Adanya pemu- } \\
& \text { lung } \\
\circ \quad \text { Kebiasaan mem- } \\
\text { buat rabuk }\end{array}$ & $\begin{array}{l}\text { TPA berada dekat } \\
\text { dengan telaga } \\
\text { menimbulkan } \\
\text { pencemaran } \\
\text { lingkungan } \\
\text { Kesadaran } \\
\text { masyarakat } \\
\text { rendah } \\
\text { Belum ada penge- } \\
\text { lolaan sampah } \\
\text { yang baik } \\
\text { Belum ada penge- } \\
\text { lolaan sampah } \\
\text { yang baik } \\
\text { Belum ada kesa- } \\
\text { daran untuk } \\
\text { pemilahan sam- } \\
\text { pah kering dan } \\
\text { basah }\end{array}$ & $\begin{array}{l}\text { Program pemerintah } \\
\text { Kebutuhan petani } \\
\text { untuk pupuk }\end{array}$ & $\begin{array}{l}\text { Kecenderung } \\
\text { an petani untuk } \\
\text { menggunakan } \\
\text { pupuk dari } \\
\text { sampah } \\
\text { anorganik }\end{array}$ \\
\hline
\end{tabular}




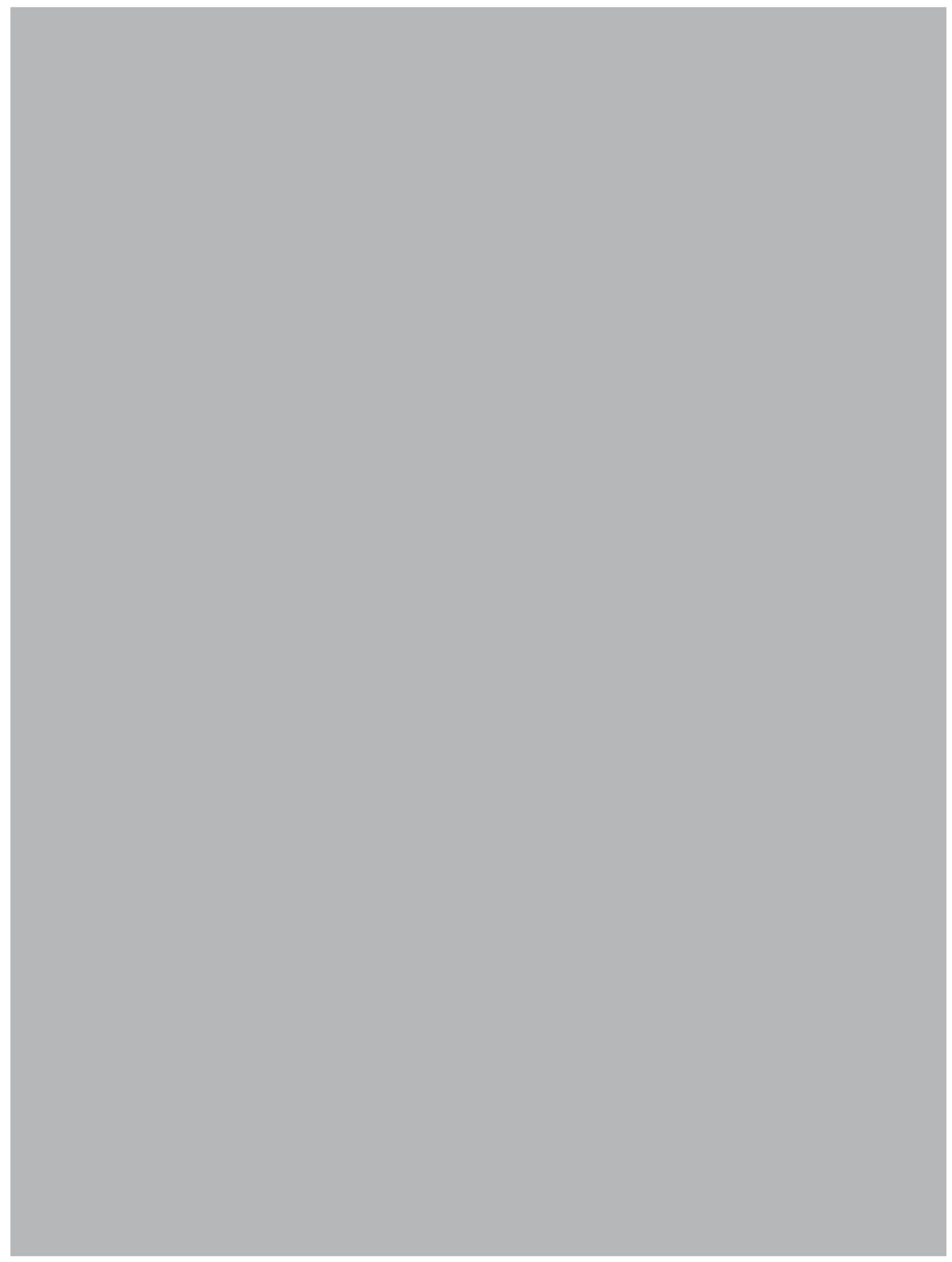


Tabel 7. Kebutuhan dan Program Potensial untuk Aspek Lingkungan

\begin{tabular}{|c|c|c|c|c|c|}
\hline Sub - Aspek & Harapan RTM & Kebutuhan & Program & Target & Lokasi \\
\hline \multirow[t]{2}{*}{ Air Bersih } & \multirow[t]{2}{*}{$\begin{array}{l}\text { Bantuan peman- } \\
\text { faatan dan } \\
\text { pengadaan air } \\
\text { bersih }\end{array}$} & $\begin{array}{l}\text { Pemanfaatan } \\
\text { sumber air bersih }\end{array}$ & $\begin{array}{l}\text { Pengembangan desa } \\
\text { dengan pendaya- } \\
\text { gunaan air bersih }\end{array}$ & \multirow[t]{2}{*}{ RTM } & Sumberdodol \\
\hline & & $\begin{array}{l}\text { Pengadaan sum- } \\
\text { ber air bersih }\end{array}$ & Pengadaan air bersih & & Metatu \\
\hline \multirow[t]{2}{*}{$\begin{array}{l}\text { Air Limbah } \\
\text { Rumahtangga }\end{array}$} & \multirow{2}{*}{$\begin{array}{l}\text { Kualitas ling- } \\
\text { kungan yang } \\
\text { bersih dan sehat }\end{array}$} & $\begin{array}{l}\text { Membangun pola } \\
\text { hidup sehat }\end{array}$ & $\begin{array}{l}\text { Penyuluhan pola } \\
\text { hidup sehat }\end{array}$ & \multirow[t]{2}{*}{ RTM } & \multirow[t]{2}{*}{$\begin{array}{l}\text { Sumberdodol } \\
\text { dan Metatu }\end{array}$} \\
\hline & & $\begin{array}{l}\text { Penyediaan } \\
\text { fasilitas sanitasi } \\
\text { yang murah, } \\
\text { bersih, dan sehat }\end{array}$ & $\begin{array}{l}\text { Subsidi fasilitas } \\
\text { sanitasi yang murah, } \\
\text { bersih, dan sehat }\end{array}$ & & \\
\hline \multirow[t]{3}{*}{ Sampah } & \multirow[t]{3}{*}{$\begin{array}{l}\text { Kualitas ling- } \\
\text { kungan yang } \\
\text { bersih dan sehat }\end{array}$} & $\begin{array}{l}\text { Peningkatan } \\
\text { kesadaran ling- } \\
\text { kungan }\end{array}$ & $\begin{array}{l}\text { Penanganan sampah } \\
\text { rumahtangga }\end{array}$ & \multirow[t]{3}{*}{ RTM } & \multirow[t]{3}{*}{$\begin{array}{l}\text { Sumberdodol } \\
\text { dan Metatu }\end{array}$} \\
\hline & & $\begin{array}{l}\text { Pemanfaatan } \\
\text { sampah }\end{array}$ & & & \\
\hline & & $\begin{array}{l}\text { Fasilitas pem- } \\
\text { buangan sampah }\end{array}$ & & & \\
\hline
\end{tabular}

Program-program yang terpilih baik antar aspek maupun subaspek memiliki banyak kesamaan, dan hubungan yang saling mendukung. Sehingga dipadukan menjadi beberapa program yang dapat memenuhi harapan dan kebutuhan RTM di semua aspek. Programprogram tersebut disajikan pada Tabel 11 dan pola hubungannya pada Gambar 3. Dari program-program yang telah dipilih maka diharapkan program-program tersebut bisa bersinergi dan berkesinambungan dalam meningkatkan tingkat kesejahteraan masyarakat RTM. Dengan meningkatnya kesejahteraan masyarakat RTM maka diharapkan bisa menurunkan angka kemiskinan.
Program yang pertama adalah pelatihan dan pendampingan wirausaha. Dari program ini, masyarakat RTM yang semula kurang terampil dalam berwirausaha diharapkan bisa terampil dengan peningkatan skill mereka dalam produksi dan pemasaran pada khususnya. Dengan meningkatnya kapasitas produksi dan penjualan pada unit usaha mereka maka keuntungan mereka akan meningkat. Jika keuntungan mereka meningkat maka pendapatan mereka akan meningkat. Pendapatan yang mereka peroleh bisa digunakan untuk memenuhi kebutuhan atau meningkatkan kesejahteraan.

Tabel 8. Pilihan Prioritas Program Aspek Sosial Budaya

\begin{tabular}{cllc}
\hline No & Sub Aspek & \multicolumn{1}{c}{ Program } & Total Score Terbobot \\
\hline 1 & Pengangguran & Menciptakan usaha produktif & 3,25 \\
2 & Pengangguran & Pelatihan dan pendampingan wirausaha & 3 \\
3 & Pendidikan & Program Paket A, B, C & 2,54 \\
4 & Pendidikan & Beasiswa & 2,54 \\
5 & Kesehatan & Penyuluhan & 1,99 \\
\hline
\end{tabular}

Pemilihan Program Pengentasan Kemiskinan (Sutikno dkk.) 


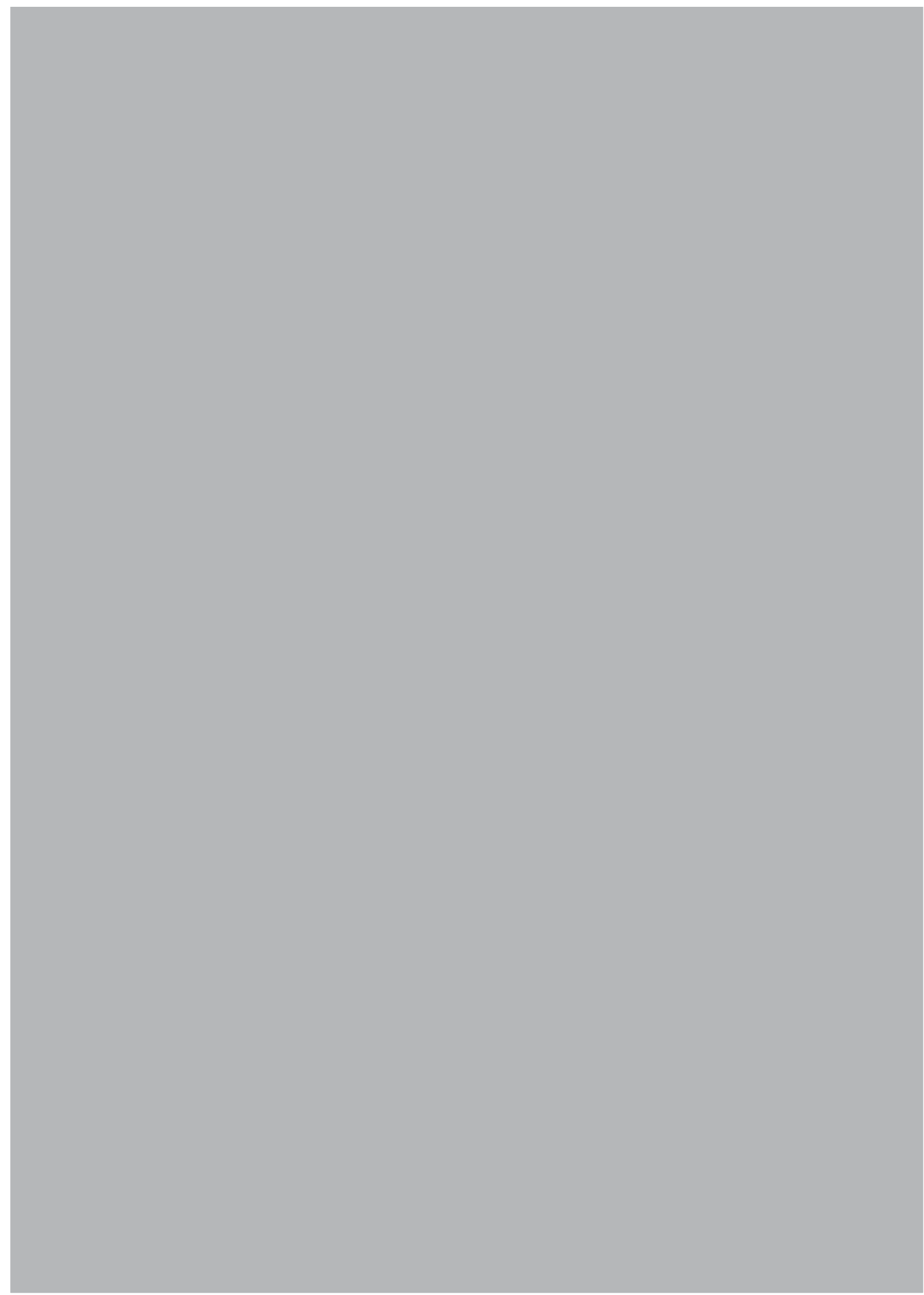


Tabel 11. Program Terpilih

\begin{tabular}{cl}
\hline No & \multicolumn{1}{c}{ Program } \\
\hline 1 & Pelatihan dan pendampingan wirausaha \\
2 & Pendirian Koperasi Simpan Pinjam \\
3 & Pengadaan air bersih untuk RTM \\
4 & Pengembangan desa dengan pendayagunaan air bersih \\
5 & Penanganan sampah rumahtangga \\
6 & Program paket A, B, dan C \\
\hline
\end{tabular}

modal usaha maka akan terjadi peningkatan kapasitas produksi yang ujungnya nanti akan meningkatkan pendapatan dan kesejahteraan masyarakat RTM.

Program ketiga adalah pendayagunaan air bersih. Program pendayagunaan air bersih di sini disesuaikan dengan kondisi di desa tersebut. Program ini bertujuan untuk dijadikan sumber pendapatan masyarakat RTM dan juga di sisi lain juga digunakan untuk meningkatkan ketersediaan air bersih. Peningkatan pendapatan tentu akan meningkatkan kesejahteraan masyarakat RTM.

Program keempat adalah pengadaan air bersih. Program pengadaan air bersih akan meningkatkan ketersediaan air bersih dan juga meningkatkan kebersihan dan kesehatan. Ketersediaan air bersih dalam keluarga RTM akan meningkatkan kesejahteraan mereka. Sedangkan kebersihan dan kesehatan akan berdampak pada berkurangnya atau terhindar dari penyakit sehingga kesejahteraan pun meningkat.

Program kelima adalah penanganan sampah rumah tangga. Pengolahan sampah rumah tangga akan menurunkan kuantitas sampah.

Penurunan tersebut akan meningkatkan kualitas kebersihan dan kesehatan yang ujungnya akan berdampak pada kesejahteraan. Selain

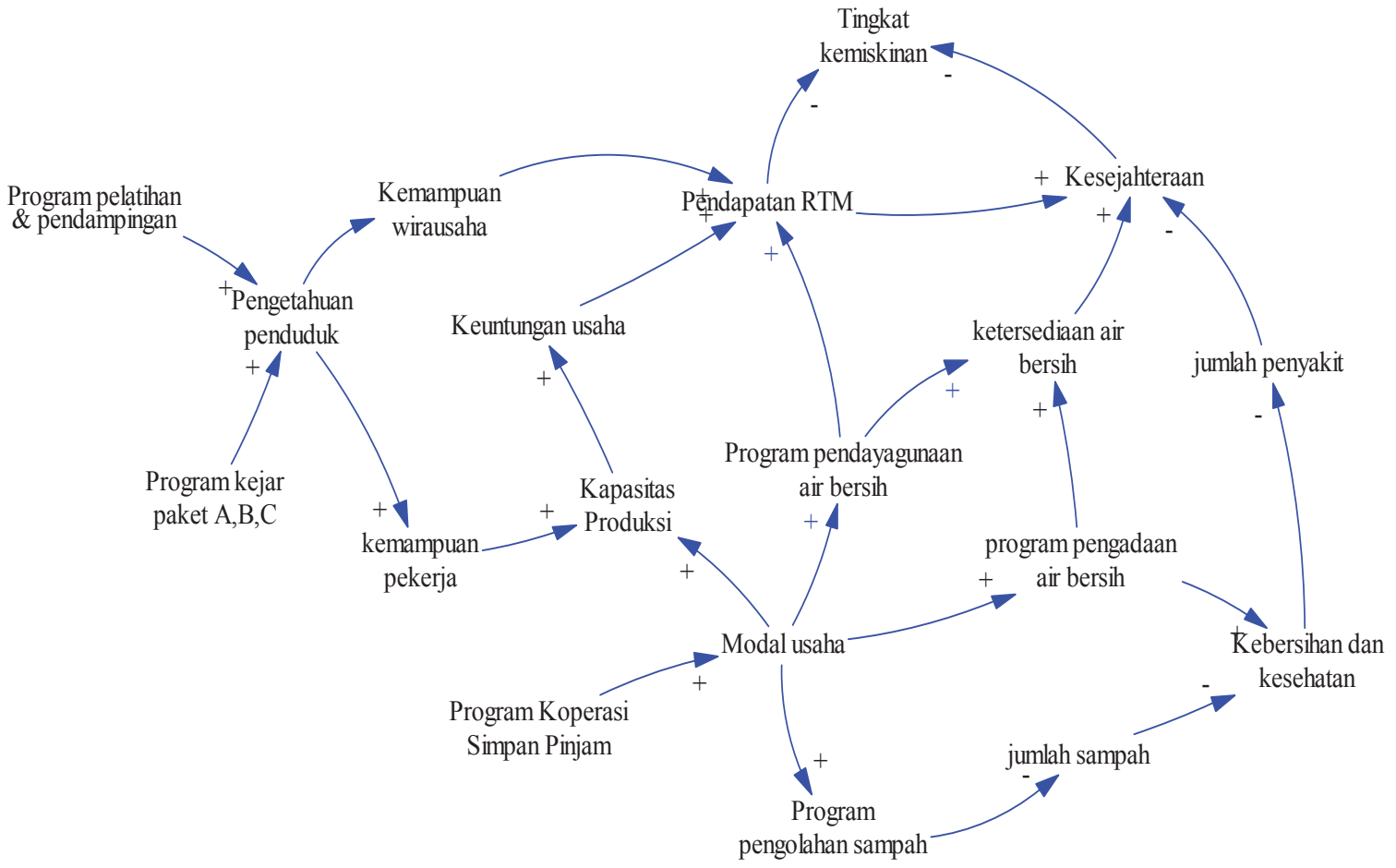

Gambar 3. Program Pemberdayaan Terpadu 
mengurangi volume sampah program pengolahan sampah juga bisa digunakan sebagai bentuk usaha daur ulang yang bisa meningkatkan pendapatan masyarakat RTM.

Program keenam adalah program kejar paket A, B, dan C. Program ini ditujukan untuk meningkatkan kemampuan masyarakat RTM dalam hal baca-tulis. Dengan meningkatnya kemampuan baca-tulis mereka bisa belajar dan meningkatkan kapasitas berwirausaha

\section{SIMPULAN}

Berdasarkan analisis SWOT dan perhitungan skoring, terpilih beberapa program potensial untuk pengentasan kemiskinan di wilayah studi menurut aspek sosial budaya, ekonomi, dan lingkungan di antaranya: pelatihan dan pendampingan wirausaha, pendirian koperasi simpan pinjam, pengadaan air bersih untuk RTM, pengembangan desa dengan pendayagunaan air bersih, penanganan sampah rumahtangga, dan program pendidikan paket $\mathrm{A}, \mathrm{B}$, dan C.

\section{DAFTAR PUSTAKA}

BPS Provinsi Jawa Timur. 2009. Profil Kemiskinan di Jawa Timur Maret 2009. Badan Statistik Provinsi Jawa Timur (http:// jatim. bps.go.id/)

Bappenas, 1994. Kaji Tindak Desa Tertinggal Tahun Pertama Yogjakarta: Aditya Media.

Bappenas. 2007. Penggunaan Hasil Evaluasi: Cara Meningkatkan Program-Program yang Berpihak pada Rakyat Miskin. (http://bappenas. go.id/) [didownload 2 Februari 2010]

Karsidi, R. 2002. Pemberdayaan Masyarakat Petani dan Nelayan Kecil. Semarang.

Listyaningsih, Umi. 2004. Dinamika Kemiskinan di Yogyakarta. Yogyakarta: Pusat Studi Kependudukan dan Kebijakan Universitas Gadjah Mada dan Partnership for Economic Growth (PEG), USAID

Nazara, Suahasil. 2008. Alternatif Kebijakan dan
Program Realistis. http://google.go. id/) [di-download 27 Maret 2009]

Nazara, Suahasil. 2008. Monitoring dan Evaluasi Program-Program Pengentasan Kemiskinan. (http://google.go.id/) [didownload 27 Maret 2009]

Rachmat. M. 2007. Analisis Perilaku Masyarakat Miskin dan Hubungan Antara Aktivitas Ekonomi dengan Derajat Kemiskinan Masyarakat Desa Tertinggal di Sepanjang Sungai Batang Hari. Jurnal Ekonomi Pembangunan FE UMS. www.google.go. id [didownload 17 Juni 2010]

Rahayu, Budiana, MG. 2008. Pembangunan Perekonomian Nasional melalui Pemberdayaan Masyarakat Desa.

www.binaswadaya.org/files/Pemberday aan-masyarakat-desa.pdf. [16 November 2009]

Rangkuti, Freddy. 1997. Analisis SWOT Teknik Membedah Kasus Bisnis. Jakarta: Gramedia Pustaka Utama.

Yasa, Murjana IG. W. 2007. Penanggulan Kemiskinan Berbasis Partisipasi Masyarakat di Provinsi Bali. (http://google. co.id/) [didownload 10 Februari 2010]

[BPS]. Badan Pusat Statistik. 2006. Berita Resmi Statistik. Tingkat Kemiskinan di Indonesia Tahun 2005-2006. Jakarta: BPS.

[UP3D] Unit Pengkajian Pengembangan Potensi Daerah. 2008. Laporan Akhir Pengembangan Model Pemberdayaan Masyarakat untuk Pengentasan Kemiskinan: Studi Kasus di Kabupaten Magetan dan Kabupaten Gresik. UP3D-LPPM ITS

[UP3D] Unit Pengkajian Pengembangan Potensi Daerah. 2008. Laporan Akhir Penyusunan Program CSR PT. Holcim Indonesia di Tuban. UP3D-LPPM ITS

[UP3D] Unit Pengkajian Pengembangan Potensi Daerah. 2006. Laporan Akhir Monitoring dan Evaluasi Program PAM DKB 2006. UP3D-LPPM ITS. 